\title{
NILAI ANAK DAN JUMLAH ANAK YANG DIINGINKAN PASANGAN USIA SUBUR DI WILAYAH PERDESAAN DAN PERKOTAAN
}

\author{
Oktriyanto $^{\left.1,2^{*}\right)}$, Herien Puspitawati ${ }^{3}$, Istiqlaliyah Muflikhati ${ }^{3}$ \\ ${ }^{1}$ Badan Kependudukan dan Keluarga Berencana (BKKBN) Pusat, Jakarta Timur 13650, Indonesia \\ ${ }^{2}$ Program Studi Ilmu Keluarga dan Perkembangan Anak, Sekolah Pascasarjana, Institut Pertanian Bogor, \\ Bogor 16680, Indonesia \\ ${ }^{3}$ Departemen IImu Keluarga dan Konsumen, Fakultas Ekologi Manusia, Institut Pertanian Bogor \\ Bogor 16680, Indonesia \\ ${ }^{*}$ E-mail: oktriyanto@yahoo.com
}

\begin{abstract}
Abstrak
Tujuan umum dari penelitian ini adalah untuk menganalisis nilai anak dan jumlah anak yang diinginkan pasangan usia subur di perdesaan dan perkotaan. Secara khusus, penelitian ini bertujuan untuk menganalisis perbedaan karakteristik keluarga, kunjungan petugas $\mathrm{KB}$, nilai anak, dan jumlah anak yang diinginkan di perdesaan dan perkotaan dan menganalisis pengaruh karakteristik keluarga, kunjungan petugas KB, dan nilai anak terhadap jumlah anak yang diinginkan. Penelitian ini menggunakan desain cross sectional. Responden penelitian ini adalah istri dari pasangan usia subur dengan usia istri berkisar 15-49 tahun di Desa Sirna Sari, Kecamatan Tanjung Sari, Kabupaten Bogor sebagai perwakilan wilayah perdesaan dan Kelurahan Gudang, Kecamatan Bogor Tengah, Kota Bogor sebagai perwakilan wilayah perkotaan. Teknik pengambilan contoh dilakukan secara cluster random sampling dengan jumlah contoh 120 orang (60 orang di perdesaan dan 60 orang di perkotaan). Hasil uji beda menunjukkan bahwa pendidikan suami, pendidikan istri dan usia kawin pertama istri, kunjungan petugas KB,nilai manfaat anak, nilai biaya anak dan jumlah anak yang diinginkan berbeda signifikan antara keluarga di perdesaan dan perkotaan. Hasil uji regresi linear berganda menunjukkan bahwa lokasi tempat tinggal, usia menikah pertama istri, jumlah anak masih hidup, pendapatan per kapita, dan kunjungan petugas KB berpengaruh signifikan terhadap jumlah anak yang diinginkan.
\end{abstract}

Kata kunci: jumlah anak yang diinginkan, nilai anak, pasangan usia subur, perdesaan, perkotaan

\section{The Value and Preferred Number of Children among Eligible Couples in Rural and Urban Areas}

\begin{abstract}
This research aimed to analyze the value of children and preferred number of children among eligible couples in rural and urban areas. Specifically, the research examined the family characteristics, the value and preferred number of children, and the visit of family planning providers between rural and urban areas; and assessed the influence of the independent variables on preferred number of children. The design of the study was cross-sectional; and involeved 60 married women aged 15-49 years old from eligible couples who resided in Sirna Sari Village, Tanjung Sari, Bogor as a representative of rural areas and 60 of those who resided in Gudang Village, Bogor Tengah, Bogor as a representative of urban areas. The results of mean test confirmed that education level of both husband and women, the age of first marriage, the visit of family planning providers, the value of children, value of children in cost dimension, and preferred number of children were different among those who lived in rural and urban areas. Moreover, the results showed that region of residence, the age of first marriage among women, living children, family income per capita, and the visit of family planning providers affected significantly preferred number of children.
\end{abstract}

Keywords: eligible couples, preferred number of children, rural area, urban area, value of children

\section{PENDAHULUAN}

Berdasarkan Sensus Penduduk 2010,
jumlah penduduk Indonesia adalah 237.556.363 jiwa, terdiri dari 119.507 .580 lakilaki dan 118.048 .783 perempuan. Lebih lanjut, angka laju pertumbuhan penduduk periode tahun 2000-2010 yaitu 1,49 persen, artinya bahwa rata-rata peningkatan jumlah penduduk Indonesia per tahun dari tahun 2000 sampai 2010 adalah sebesar 1,49 persen/tahun. Salah satu upaya pemerintah dalam mengendalikan laju pertumbuhan penduduk adalah melalui pelaksanaan program keluarga berencana (KB) bagi pasangan usia subur. Berdasarkan Undang-Undang RI No.52 tahun 2009, keluarga 
berencana adalah upaya mengatur kelahiran anak, jarak dan usia ideal melahirkan, mengatur kehamilan, melalui promosi, perlindungan, dan bantuan sesuai dengan hak reproduksi untuk mewujudkan keluarga yang berkualitas.

Salah satu indikator keberhasilan pemerintah dalam program KB dapat dilihat dari angka kelahiran total/total fertility rate (TFR). Berdasarkan data Survei Demografi dan Kesehatan Indonesia (SDKI) menunjukkan adanya penurunan dari 3 anak per wanita pada SDKI 1991 menjadi 2,6 anak pada SDKI 20022003. Setelah itu tingkat fertilitas tidak mengalami perubahan (stagnant) baik pada SDKI 2007 maupun SDKI 2012 yaitu TFR masih sebesar 2,6. Dengan TFR yang mengalami stagnant, hal ini akan sangat sulit bagi pemerintah untuk mencapai target pemerintah dalam RPJMN 2010-2014 yaitu TFR sebesar 2,1 (BKKBN et al., 2013).

Jumlah anak yang diinginkan merupakan salah satu faktor yang memengaruhi TFR. Jumlah anak yang diinginkan sebenarnya bukan merupakan variabel langsung yang berhubungan dengan fertilitas, namun berhubungan dengan variabel yang memengaruhi salah satu variabel antara, yaitu pengaturan kelahiran (Davis \& Blake, 1956). Menurut Singh et al. (2010) banyak keluarga akan terus memiliki anak setelah mencapai ukuran keluarga yang diinginkan. Keputusan untuk memiliki sejumlah anak adalah sebuah pilihan, yang mana pilihan tersebut sangat dipengaruhi oleh beberapa hal. Pertama, kunjungan petugas $\mathrm{KB}$ yang memberikan motivasi mengenai norma keluarga kecil bahagia sejahtera atau NKKBS (Suyono, Soedarmadi, \& Noerdin, 2013). Kedua, kecenderungan orang tua dalam memaknai kehadiran anak (nilai anak). Hasil penelitian faktor-faktor yang memengaruhi jumlah anak yang diinginkan oleh keluarga Pasangan Usia Subur (PUS) yang bekerja di Kecamatan Kota Madiun menemukan bahwa jumlah jam kerja, status sosial ekonomi, dan usia menikah pertama istri berpengaruh signifikan terhadap jumlah anak yang diinginkan (Rahayu, 2009). Keluarga yang menganggap bahwa nilai manfaat anak lebih tinggi dibandingkan dengan nilai biaya anak, maka akan memiliki kecendrungan memiliki jumlah anak yang banyak (Bulatao \& Lee, 1983). Selanjutnya, hasil penelitian lintas budaya 12 negara yang dilakukan oleh Trommsdorff dan Mayer (2010) menemukan bahwa nilai anak (emosi) memiliki hubungan positif terhadap jumlah anak yang diinginkan remaja di masa yang akan datang.
Penelitian mengenai nilai anak sudah banyak dilakukan di berbagai negara, namun demikian sedikit sekali studi yang melihat nilai anak dari dua dimensi sekaligus yaitu dimensi manfaat dan dimensi biaya. Studi sebelumnya lebih banyak melihat nilai anak dari dimensi manfaat atau dari nilai biaya anak (biaya ekonomi) saja. Selain itu, penelitian yang memasukkan variabel mengenai kunjungan petugas KB dan nilai anak sebagai variabel yang memengaruhi jumlah anak yang diinginkan jumlahnya masih sangat sedikit. Penelitian ini menjadi penting dilakukan untuk mengetahui nilai anak dan jumlah anak yang diinginkan pasangan usia subur di perdesaan dan perkotaan. Secara khusus tujuan penelitian ini adalah menganalisis perbedaan karakteristik keluarga, kunjungan Petugas KB, nilai anak dan jumlah anak yang diinginkan di perdesaan dan perkotaan dan menganalisis pengaruh karakteristik keluarga, kunjungan petugas KB dan nilai anak terhadap jumlah anak yang diinginkan.

\section{METODE}

Penelitian ini menggunakan desain cross sectional. Lokasi penelitian dipilih secara purposive, yaitu di Desa Sirna Sari, Kecamatan Tanjung Sari Kabupaten Bogor (yang selanjutnya akan disebutkan sebagai wilayah "desa") dan di Kelurahan Gudang, Kecamatan Bogor Tengah, Kota Bogor (yang selanjutnya akan disebutkan sebagai wilayah "kota"). Waktu yang digunakan dalam penelitian ini selama 8 bulan, terhitung dimulai pada bulan Maret 2014 hingga Oktober 2014 meliputi tahap persiapan, pengumpulan data, pengolahan data, dan penulisan.

Populasi penelitian ini adalah Pasangan Usia Subur (PUS) dengan usia istri berkisar antara 15-49 tahun di lokasi terpilih. Teknik penarikan contoh dilakukan secara cluster random sampling dengan jumlah contoh sebanyak 120 contoh yang terdiri dari 60 contoh di Desa Sirnasari dan 60 contoh di Kelurahan Gudang. Responden penelitian ini adalah istri.

Data yang dikumpulkan melalui wawancara tatap muka dengan menggunakan kuesioner meliputi: (1) data karakteristik keluarga, (2) data kunjungan petugas KB, (3) data nilai anak, dan (4) data jumlah anak yang diinginkan. Instrumen nilai anak diukur berdasarkan Value of Children (VOC) Scale yang dikembangkan oleh Arnold et al. (1975), Buripakdi (1977), dan Lucas \& Meyer (1990) dengan beberapa modifikasi yang dilakukan 
peneliti. Instrumen yang digunakan untuk mengukur nilai manfaat anak maupun nilai biaya anak telah reliabel dengan nilai Cronbach's alpha masing masing sebesar 0,953 dan 0,854 .

Instrumen nilai manfaat anak penelitian ini terdiri dari 16 pertanyaan yaitu: (1) anak membawa kegembiraan dan kebahagiaan, (2) menghilangkan rasa kesepian, (3) memberikan rasa bangga, (4) membantu pekerjaan rumah, (5) membantu ekonomi keluarga, (6) merawat di saat sakit, (7) merawat dan menjaga di saat lanjut usia, (8) membuat lebih baik dan bertanggung jawab, (9) membuat lebih dihargai di masyarakat, (10) membuat lebih bersemangat dalam hidup, (11) memperkuat ikatan perkawinan, (12) penerus garis keturunan, (13) menggantikan posisi orang tua, (14) merasa sempurna sebagai wanita, (15) mendatangkan berkah, dan (16) mendoakan orang tua. Sementara itu, instrumen nilai biaya anak dalam penelitian ini terdiri dari 16 pertanyaan yaitu: (1) kekhawatiran terhadap perilaku anak, (2) kekhawatiran terhadap keamanan anak, (3) kekhawatiran terhadap kesehatan anak, (4) membuat jengkel dan kesal, (5) biaya hidup keluarga, (6) biaya kesehatan, (7) biaya sekolah, (8) suami lebih perhatian terhadap anak, (9) sulit bekerja/meningkatkan karir, (10) sulit mengerjakan pekerjaan rumah, (11) sulit berkumpul dengan teman dan saudara, (12) membuat capek dan lelah, (13) sulit merawat diri, (14) jadwal tidur dan makan terganggu, (15) kebersamaan dengan pasangan terganggu, dan (16) menyebabkan pertengkaran dengan pasangan.

Setiap pertanyaan nilai anak diberi pilihan jawaban, yaitu 1 untuk jawaban "tidak setuju", 2 untuk jawaban "kurang setuju, 3 untuk jawaban "setuju", dan 4 untuk jawaban "sangat setuju". Setelah diperoleh data nilai manfaat dan nilai biaya anak kemudian dihitung indeksnya dan dikategorikan menjadi tiga kategori yaitu rendah (indeks < 60), sedang (indeks 60-80), dan tinggi (indeks $>80$ ).

Analisis data yang digunakan dalam penelitian ini yaitu analisis deskriptif dan inferensial (uji beda dan regresi linear berganda). Analisis deskriptif dilakukan untuk menganalisis karakteristik keluarga, kunjungan petugas KB, nilai anak, dan jumlah anak yang diinginkan. Sementara itu, analisis uji beda dilakukan untuk menganlisis perbedaan karakteristik keluarga, nilai anak dan jumlah anak yang diinginkan pada keluarga yang tinggal di perdesaan dan perkotaan. Analisis regresi linear berganda digunakan untuk menganalisis pengaruh karakteristik keluarga, kunjungan petugas KB dan nilai anak terhadap jumlah anak yang diinginkan.

\section{HASIL}

\section{Karakteristik Keluarga}

Hasil penelitan menunjukkan bahwa ratarata usia suami lebih tua daripada usia istri masing-masing adalah 38,68 dan 32,78 tahun. Berdasarkan tingkat pendidikan, pendidikan suami lebih tinggi daripada pendidikan istri. Rata-rata lama pendidikan suami adalah 8,23 tahun, sedangkan rata-rata lama pendidikan istri adalah 7,67 tahun. Sebagian besar istri dari keluarga tidak bekerja (77,5\%). Berdasarkan pendapatan per kapita, Rata-rata pendapatan per kapita keluarga sebesar Rp588.100. Ratarata usia menikah pertama istri adalah 18,86 tahun dan lama menikah istri adalah 13,09 tahun. Selanjutnya, rata-rata jumlah anak lahir hidup dan jumlah anak masih hidup masingmasing sebesar 2,21 anak dan 2,04 anak, artinya terdapat 7,69 persen anak dalam keluarga yang meninggal dunia.

Tabel 1 Rata-rata dan standar deviasi karakteristik keluarga berdasarkan lokasi tempat tinggal

\begin{tabular}{|c|c|c|c|}
\hline $\begin{array}{c}\text { Karakteristik } \\
\text { keluarga }\end{array}$ & Desa & Kota & $p$-value \\
\hline $\begin{array}{l}\text { Usia suami } \\
\text { (tahun) }\end{array}$ & $\begin{array}{c}38,75 \pm \\
9,17\end{array}$ & $\begin{array}{c}38,60 \pm \\
7,95\end{array}$ & 0,924 \\
\hline $\begin{array}{l}\text { Usia istri } \\
\text { (tahun) }\end{array}$ & $\begin{array}{c}32,58 \pm \\
7.89\end{array}$ & $\begin{array}{c}32,97 \pm \\
7,10\end{array}$ & 0,780 \\
\hline $\begin{array}{l}\text { Lama } \\
\text { pendidikan } \\
\text { suami (tahun) }\end{array}$ & $\begin{array}{c}7,07 \pm \\
2,14\end{array}$ & $\begin{array}{c}9,40 \pm \\
3,32\end{array}$ & $0,000^{\star *}$ \\
\hline $\begin{array}{l}\text { Lama } \\
\text { pendidikan } \\
\text { istri (tahun) }\end{array}$ & $\begin{array}{c}6,67 \pm \\
2,19\end{array}$ & $\begin{array}{c}8,67 \pm \\
2,56\end{array}$ & $0,000^{\star *}$ \\
\hline $\begin{array}{l}\text { Usia menikah } \\
\text { pertama istri } \\
\text { (tahun) }\end{array}$ & $\begin{array}{c}17,45 \pm \\
2,31\end{array}$ & $\begin{array}{c}20,27 \pm \\
2,73\end{array}$ & $0,000^{* *}$ \\
\hline $\begin{array}{l}\text { Lama } \\
\text { menikah istri } \\
\text { (tahun) }\end{array}$ & $\begin{array}{c}13,50 \pm \\
7,07\end{array}$ & $\begin{array}{c}12,68 \pm \\
7,62\end{array}$ & 0,544 \\
\hline $\begin{array}{l}\text { Jumlah anak } \\
\text { lahir hidup } \\
\text { (jiwa) }\end{array}$ & $\begin{array}{c}2,27 \pm \\
1,65\end{array}$ & $\begin{array}{c}2,15 \pm \\
1,15\end{array}$ & 0,653 \\
\hline $\begin{array}{l}\text { Jumlah anak } \\
\text { masih hidup } \\
\text { (jiwa) }\end{array}$ & $\begin{array}{c}2,00 \pm \\
1,21\end{array}$ & $\begin{array}{c}2,08 \pm \\
1,10\end{array}$ & 0,693 \\
\hline $\begin{array}{l}\text { Pendapatan } \\
\text { per kapita } \\
\text { (Rp/ bulan) }\end{array}$ & $\begin{array}{c}559.800 \\
\pm \\
395.090\end{array}$ & $\begin{array}{c}616.300 \\
\pm \\
363.090\end{array}$ & 0,416 \\
\hline
\end{tabular}

Keterangan:

** Signifikan pada $p<0,01$ 
Hasil uji beda yang disajikan pada Tabel 1 menunjukkan bahwa pendidikan suami, pendidikan istri, dan usia menikah pertama istri antara keluarga di wilayah perdesaan dan perkotaan terdapat berbeda signifikan $(p<0,01)$. Lama pendidikan suami dan istri di wilayah perkotaan lebih tinggi daripada di lama pendidikan suami dan istri di wilayah perdesaan. Rata-rata usia menikah pertama istri di wilayah perdesaan lebih rendah daripada di wilayah perkotaan.

\section{Kunjungan Petugas KB}

Sebagian besar istri $(66,7 \%)$ menyatakan bahwa dalam kurun waktu 6 bulan terakhir ada petugas KB (PLKB, Pos KB/Sub Pos KB/Kader $K B$, atau Petugas Kesehatan) yang berkunjung untuk memberikan penyuluhan mengenai program Keluarga Berencana. Keluarga yang tinggal di wilayah perdesaan mendapatkan kunjungan petugas KB lebih sedikit (56,7\%) dibandingkan dengan keluarga di wilayah perkotaan $(76,7 \%)$. Hasil uji beda menggunakan uji beda Mann-Whitney memperlihatkan bahwa terdapat perbedaan yang signifikan pada kunjungan petugas $\mathrm{KB}$ antara keluarga di wilayah perdesaan dan perkotaan $(p<0,05)$. Sebaran keluarga di wilayah perdesaan dan perkotaan berdasarkan kunjungan petugas KB disajikan pada Tabel 2.

\section{Nilai Anak}

Nilai anak merupakan nilai yang diperoleh orang tua yang terdiri dari nilai positif (manfaat) dan nilai negatif (kerugian dan biaya) ketika memiliki anak (Buchori, 2011). Nilai positif dan negatif dari anak dapat diperoleh dari tanggapan orang tua terkait dengan: (1) keuntungan atau manfaat dari memiliki anak, (2) kerugian dari memiliki anak, (3) persepsi mengapa orang lain dalam masyarakat ingin memiliki anak, (4) alasan menginginkan anak perempuan dan anak laki-laki, (5) intensitas preferensi anak laki-laki, dan (6) alasan ingin jumlah tertentu mengenai anak (Buripakdi, 1977).

Tabel 2 Sebaran keluarga di wilayah perdesaan dan perkotaan berdasarkan kunjungan petugas KB

\begin{tabular}{lcrr}
\hline $\begin{array}{l}\text { Kunjungan Petugas } \\
\text { KB }\end{array}$ & $\begin{array}{c}\text { Desa } \\
(\%)\end{array}$ & $\begin{array}{c}\text { Kota } \\
(\%)\end{array}$ & \multicolumn{1}{c}{$\begin{array}{c}\text { Total } \\
(\%)\end{array}$} \\
\hline Pernah & 56,7 & 76,7 & 66,7 \\
Tidak Pernah & 43,3 & 23,3 & 33,3 \\
\hline Total & 100 & 100,0 & 100,0 \\
$p$-value & $0,021^{*}$ & \\
\hline Keterangan: & \multicolumn{4}{|}{} \\
*Signifikan pada $p<0,05$ & &
\end{tabular}

Hasil penelitian menunjukkan bahwa secara keseluruhan rata-rata indeks nilai manfaat anak dalam penelitian ini termasuk dalam kategori tinggi. Sementara itu, apabila dikategorikan maka ditemukan sebanyak 80,8 persen nilai anak dalam kategori tinggi, 19,2 persen dalam kategori sedang, dan tidak ada satu pun istri yang mempunyai nilai anak dalam kategori rendah (Tabel 3). Hasil penelitian menunjukkan bahwa rata-rata indeks nilai manfaat anak di wilayah perdesaan $(94,85)$ cenderung lebih tinggi dibandingkan dengan nilai manfaat anak di wilayah perkotaan $(86,98)$. Hasil uji beda $t$ menunjukkan bahwa terdapat perbedaan yang signifikan antara nilai manfaat anak keluarga di wilayah perdesaan dan wilayah perkotaan $(p<0,01)$. Dengan demikian, keluarga di wilayah perdesaan mempersepsikan anak lebih tinggi sebagai sumber manfaat dibandingkan keluarga di wilayah perkotaan.

Nilai anak juga dilihat dari biaya (nilai biaya). Sebanyak 12,5 persen nilai biaya anak dalam kategori tinggi, 25,0 persen dalam kategori sedang, dan sebanyak 62,5 persen dalam kategori rendah (Tabel 3). Hasil tersebut menunjukkan bahwa hanya satu dari delapan istri yang mempersepsikan anaknya memberikan beban ekonomi yang tinggi bagi keluarga. Hasil uji beda $t$ menunjukkan bahwa terdapat perbedaan yang signifikan antara nilai biaya anak di wilayah perdesaan dan perkotaan $(p<0,01)$. Nilai biaya anak di wilayah perdesaan lebih rendah dibandingkan dengan nilai biaya anak di wilayah perkotaan.

Tabel 3 Sebaran keluarga di wilayah perdesaan dan perkotaan berdasarkan nilai manfaat dan nilai biaya anak

\begin{tabular}{lrrr}
\hline Kategori & \multicolumn{1}{c}{ Desa } & \multicolumn{1}{c}{ Kota } & \multicolumn{1}{c}{ Total } \\
\hline Nilai manfaat & \multicolumn{4}{c}{0} \\
Rendah & 0,0 & 0,0 & 0,0 \\
Sedang & 5,0 & 33,3 & 19,2 \\
Tinggi & 95,0 & 66,7 & 80,8 \\
Total & 100,0 & 100,0 & 100,0 \\
Rata-rata \pm & $94,85 \pm$ & $86,98 \pm$ & $90,92 \pm$ \\
standar deviasi & 7,05 & 15,34 & 12,52 \\
Min-maks & $66-100$ & $62-100$ & $62-100$ \\
p-value & $0,000^{* *}$ & \\
\hline Nilai biaya & \multicolumn{4}{c}{} \\
Rendah & 90,0 & 35,0 & 62,5 \\
Sedang & 8,3 & 41,7 & 25,0 \\
Tinggi & 1,7 & 23,3 & 12,5 \\
Total & 100,0 & 100,0 & 100,0 \\
Rata-rata \pm & $38,83 \pm$ & $63,55 \pm$ & $51,19 \pm$ \\
standar deviasi & 14,65 & 21,58 & 22,17 \\
Min-maks & $18-83$ & $6-97$ & $6-97$ \\
p-value & $0,000^{* *}$ & \\
\hline Keterangan: ** Signifikan pada $\mathrm{p}<0,01$ &
\end{tabular}




\section{Jumlah Anak yang Diinginkan}

Jumlah anak yang diinginkan adalah banyaknya anak yang diinginkan oleh istri selama masa hidupnya. Jumlah anak yang diinginkan dalam penelitian ini dikategorikan menjadi 2 kelompok yaitu keinginan memiliki anak $\leq 2$ anak dan keinginan memiliki anak $>2$ anak. Hasil penelitian menunjukkan bahwa 54,2 persen istri menginginkan jumlah anak lebih dari dua orang. Jumlah anak yang diinginkan minimum adalah satu orang dan maksimum adalah delapan orang. Rata-rata jumlah anak yang diinginkan dalam penelitian ini adalah tiga orang. Hasil penelitian menunjukkan bahwa tidak ada satupun istri yang tidak menginginkan anak. Sebaran keluarga di wilayah perdesaan dan perkotaan berdasarkan jumlah anak yang diinginkan disajikan pada Tabel 5.

Jumlah anak yang diingin keluarga di wilayah perdesaan dan perkotaan berbeda signifikan. Jumlah anak yang diinginkan oleh keluarga yang tinggal di wilayah perdesaan lebih banyak dibandingkan dengan jumlah anak yang diinginkan oleh keluarga yang tinggal di wilayah perkotaan. Meskipun keluarga di perdesaan pada umumnya jumlah anak yang diinginkan lebih banyak daripada keluarga di wilayah perkotaan, jumlah anak yang diinginkan pada sebagian dari keluarga di wilayah perdesaan khususnya yang bekerja di sektor pertanian telah mengalami perubahan. Nilai manfaat anak menurun sehingga jumlah anak yang diinginkan juga menurun. Rosenzweig (1977) dalam penelitiannya menemukan bahwa penurunan nilai anak sebagai aset produktif di bidang pertanian merupakan faktor dalam penurunan angka kelahiran di wilayah pertanian Amerika Serikat.

Tabel 5 Sebaran keluarga di wilayah perdesaan dan perkotaan berdasarkan jumlah anak yang diinginkan

\begin{tabular}{|c|c|c|c|}
\hline $\begin{array}{l}\text { Jumlah anak } \\
\text { yang diinginkan }\end{array}$ & Desa & Kota & Total \\
\hline$\leq 2$ anak & 13,3 & 78,3 & 45,8 \\
\hline$>2$ anak & 86,7 & 21,7 & 54,2 \\
\hline Total & 100,0 & 100,0 & 100,0 \\
\hline $\begin{array}{l}\text { Rata-rata } \pm \\
\text { Standar deviasi } \\
\text { (anak) }\end{array}$ & $\begin{array}{c}4,07 \pm \\
1,43\end{array}$ & $\begin{array}{c}2,22 \pm \\
0,72\end{array}$ & $\begin{array}{c}3,14 \pm \\
1,46\end{array}$ \\
\hline $\begin{array}{l}\text { Minimum- } \\
\text { maksimum } \\
\text { (anak) }\end{array}$ & $2-8$ & $1-4$ & $1-8$ \\
\hline$p$-value & \multicolumn{2}{|c|}{$0,000^{* *}$} & \\
\hline
\end{tabular}

Keterangan:

** Signifikan pada $p<0,01$
Tabel 6 Sebaran keluarga berdasarkan kesenjangan antara jumlah anak yang diinginkan dengan jumlah anak masih hidup

\begin{tabular}{|c|c|c|c|}
\hline Variabel & Desa & Kota & Total \\
\hline \multicolumn{4}{|c|}{ Kesenjangan jumlah anak } \\
\hline $\begin{array}{l}\text { Jumlah anak yang } \\
\text { diinginkan > jumlah } \\
\text { anak yang masih } \\
\text { hidup }\end{array}$ & 91,7 & 33,3 & 62,5 \\
\hline $\begin{array}{l}\text { Jumlah anak yang } \\
\text { diinginkan < jumlah } \\
\text { anak yang masih } \\
\text { hidup }\end{array}$ & 3,3 & 21,7 & 12,5 \\
\hline $\begin{array}{l}\text { Jumlah anak yang } \\
\text { diinginkan = jumlah } \\
\text { anak yang masih } \\
\text { hidup }\end{array}$ & 5,0 & 45,0 & 25,0 \\
\hline Total & 100,0 & 100,0 & 100,0 \\
\hline \multicolumn{4}{|c|}{ Preferensi jenis kelamin } \\
\hline $\begin{array}{l}\text { Jumlah anak laki- } \\
\text { laki>anak perempuan }\end{array}$ & 6,7 & 8,3 & 7,5 \\
\hline $\begin{array}{l}\text { Jumlah anak laki- } \\
\text { laki<anak perempuan }\end{array}$ & 30,0 & 13,3 & 21,7 \\
\hline $\begin{array}{l}\text { Jumlah anak laki- } \\
\text { laki=anak perempuan }\end{array}$ & 60,0 & 56,7 & 58,3 \\
\hline $\begin{array}{l}\text { Tidak memper- } \\
\text { masalah-kan jenis } \\
\text { kelamin }\end{array}$ & 3,3 & 21,7 & 12,5 \\
\hline Total & 100,0 & 100,0 & 100,0 \\
\hline
\end{tabular}

Jumlah anak yang diinginkan keluarga tidak selalu sama dengan jumlah anak yang masih hidup. Artinya, jumlah anak masih hidup ada yang lebih banyak dari jumlah anak yang diinginkan dan ada juga yang lebih sedikit dibandingkan dengan jumlah anak yang diinginkan. Sebagian besar keluarga $(62,5 \%)$, memiliki jumlah anak masih hidup lebih kecil daripada jumlah anak yang diinginkan. Sebagian besar keluarga di perdesaan jumlah anak masih hidup lebih kecil dari jumlah anak yang diinginkan. Sementara itu, proporsi terbesar keluarga di perkotaan adalah adanya jumlah yang sama antara jumlah anak yang diinginkan dengan anak yang masih hidup. Temuan ini menunjukkan bahwa keluarga di perkotaan lebih terpenuhi harapannya dalam memiliki anak.

Secara umum, sebagian besar $(58,3 \%)$ istri menginginkan jumlah anak laki-laki sama besarnya dengan jumlah anak perempuan (Tabel 6). Ditinjau dari lokasi tempat tinggal, sebagian besar istri pada keluarga di wilayah perdesaan maupun di perkotaan menginginkan jumlah anak laki-laki yang sama dengan jumlah anak perempuan. Temuan yang menarik dari penelitian ini menunjukkan bahwa satu perlima istri tidak mempermasalahkan jenis kelamin anak, jumlahnya lebih banyak perempuan atau 
laki-laki. Orang tua yang tidak mempermasalahkan jenis kelamin anak mengemukakan alasan bahwa anak adalah pemberian Tuhan sehingga tidak bisa menentukan jenis kelamin anak, dengan demikian apapun jenis kelaminnya orang tua tetap bersyukur. Sementara itu, di perdesaan, proporsi keluarga yang mempertimbangkan jumlah anak berdasarkan jenis kelamin lebih besar. Hanya 1 dari 30 istri pada keluarga perdesaan yang tidak mempermasalahkan jenis kelamin.

\section{Pengaruh Karakteristik Keluarga, Kunjung- an Petugas KB, dan Nilai Anak terhadap Jumlah Anak yang Diinginkan}

Pengaruh karakteristik keluarga, kunjungan petugas $\mathrm{KB}$, dan nilai anak terhadap jumlah anak dianalisis menggunakan uji regresi linear berganda. Variabel bebas (independent) yang digunakan adalah lokasi tempat tinggal, usia istri, pendidikan suami, pendidikan istri, status bekerja istri, usia menikah pertama istri, jumlah anak masih hidup, kehilangan kehamilan, pendapatan per kapita, kunjungan petugas KB, nilai manfaat anak, dan nilai biaya anak dengan variabel terikat adalah jumlah anak yang diinginkan pasangan. Berdasarkan uji korelasi yang dilakukan ditemukan variabel usia suami dengan usia istri, lama menikah dengan usia suami, lama menikah dengan usia istri, dan jumlah anak lahir hidup dengan jumlah anak masih hidup mempunyai hubungan yang sangat kuat dan bersifat multikolinear. Untuk menghindari bias data maka salah satu variabel dieliminasi dari model. Variabel yang dieliminasi adalah usia suami, jumlah anak lahir hidup, dan lama menikah.

Model yang disusun untuk menganalisis pengaruh karakteristik keluarga, kunjungan petugas $\mathrm{KB}$, dan nilai anak terhadap jumlah anak memiliki koefisien determinasi (Adjusted $R$ Square) sebesar 0,524 , artinya sebesar 52,4 persen jumlah anak yang diinginkan dapat dijelaskan oleh variabel bebas dalam model dan sisanya sebesar 47,6 persen dipengaruhi oleh variabel lain yang tidak diteliti dalam penelitian ini. Hasil uji regresi menunjukkan bahwa usia istri, lama pendidikan suami, lama pendidikan istri, status bekerja istri, kehilangan kehamilan (keguguran, lahir mati), nilai manfaat anak, dan nilai biaya anak tidak berpengaruh signifikan $(p>0,05)$ terhadap jumlah anak yang diinginkan pasangan usia subur. Jumlah anak yang diinginkan dipengaruhi oleh lokasi tempat tinggal, usia menikah pertama istri, jumlah anak masih hidup, pendapatan per kapita, dan kunjungan petugas KB.
Tabel 8 Koefisien regresi untuk analisis pengaruh karakteristik keluarga, kunjungan petugas $\mathrm{KB}$, dan nilai anak terhadap jumlah anak yang diinginkan pasangan usia subur

\begin{tabular}{|c|c|c|c|}
\hline \multirow{2}{*}{ Variabel } & \multicolumn{2}{|c|}{ Koefesien } & \multirow{2}{*}{ Sig. } \\
\hline & $\mathrm{B}$ & $\beta$ & \\
\hline $\begin{array}{l}\text { Lokasi tempat } \\
\text { tinggal }(0=\text { desa, } 1= \\
\text { kota) }\end{array}$ & $-1,221$ & $-0,421$ & $0,000^{* *}$ \\
\hline Usia istri (tahun) & $-0,019$ & $-0,099$ & 0,240 \\
\hline $\begin{array}{l}\text { Pendidikan suami } \\
\text { (tahun) }\end{array}$ & 0,037 & 0,076 & 0,367 \\
\hline $\begin{array}{l}\text { Pendidikan istri } \\
\text { (tahun) }\end{array}$ & $-0,058$ & $-0,102$ & 0,227 \\
\hline $\begin{array}{l}\text { Status bekerja istri } \\
(0=\text { tidak bekerja, } \\
1=\text { bekerja })\end{array}$ & 0,034 & 0,010 & 0,886 \\
\hline $\begin{array}{l}\text { Usia menikah } \\
\text { pertama istri } \\
\text { (tahun) }\end{array}$ & $-0,085$ & $-0,169$ & $0,056^{\star}$ \\
\hline $\begin{array}{l}\text { Jumlah anak } \\
\text { masih hidup (jiwa) }\end{array}$ & 0,277 & 0,219 & $0,018^{*}$ \\
\hline $\begin{array}{l}\text { Kehilangan } \\
\text { kehamilan }(0= \\
\text { tidak pernah, } 1= \\
\text { pernah) }\end{array}$ & 0,183 & 0,056 & 0,408 \\
\hline $\begin{array}{l}\text { Pendapatan per } \\
\text { kapita }(\mathrm{Rp} / \mathrm{bln})\end{array}$ & 6,33E-7 & $-0,165$ & $0,037^{\star}$ \\
\hline $\begin{array}{l}\text { Kunjungan } \\
\text { petugas KB } \\
\text { ( } 0=\text { tidak pernah, } \\
1=\text { pernah) }\end{array}$ & $-0,492$ & $-0,160$ & $0,020^{*}$ \\
\hline $\begin{array}{l}\text { Nilai manfaat anak } \\
\text { (indeks) }\end{array}$ & 0,009 & 0,080 & 0,257 \\
\hline $\begin{array}{l}\text { Nilai biaya anak } \\
\text { (indeks) }\end{array}$ & $-0,006$ & $-0,093$ & 0,288 \\
\hline$F$ & & & 11,931 \\
\hline Sig. & & & $0,000^{* *}$ \\
\hline $\mathrm{R} 2$ & & & 0,572 \\
\hline Adjusted R2 & & & 0,524 \\
\hline
\end{tabular}

Keterangan:

$\mathrm{B}=$ Tidak terstandardisasi, $\beta=$ Terstandardisasi,

*Signifikan pada $p<0,10$, *Signifikan pada $p<0,05$, **Signifikan pada $p<0,01$

\section{PEMBAHASAN}

Penelitian ini mengangkat pentingnya nilai anak dan kaitannya dengan jumlah anak yang diinginkan pasangan usia subur di perdesaan dan perkotaan. Menurut Friedman, Michael, \& Kanazawa (1994), dalam keadaan tradisional, anak-anak sangatlah penting untuk mengurangi ketidakpastian, baik karena kemampuan mereka untuk memberikan kekayaan dan asuransi untuk orang tua mereka di usia lanjut (lansia) dan atas kontribusi mereka terhadap integrasi sosial. Akan tetapi, dengan perubahan waktu terjadi pergeseran nilai dimana terjadi penurunan jumlah anak yang diinginkan dari 
jumlah anak banyak menjadi jumlah anak sedikit (seperti halnya teori ekonomi penurunan kesuburan), meskipun menuntut harus mengurangi tetapi tidak sampai nol atau tidak menginginkan anak.

Jumlah anak yang diinginkan keluarga di perdesaan dalam penelitian ini cenderung lebih banyak daripada keluarga di perkotaan. Menurut Schultz (1997), seseorang yang memiliki lahan pertanian yang luas biasanya menginginkan jumlah anak yang relatif tinggi karena orang tua akan menutup biaya melahirkan anak dengan menggunakan anak untuk menggantikan mahalnya menyewa buruh tani. Biaya bersih anak (net costs of children) di perkotaan dianggap lebih tinggi karena ada pekerjaan yang kurang produktif di sana untuk anak dalam keluarga, seperti biaya makanan, tempat tinggal, dan biaya kursus yang lebih besar.

Usia menikah pertama istri di perdesaan dalam penelitian ini cenderung lebih rendah daripada di perkotaan. Hal ini diakibatkan oleh pendidikan istri di perdesaan lebih rendah daripada di perkotaan. Kesempatan perempuan untuk memperoleh pendidikan yang lebih tinggi semakin terbuka pada saat ini sehingga menyebabkan banyak perempuan menunda perkawinan. Perempuan berpendidikan tinggi cenderung memilih terjun ke pasar kerja terlebih dahulu sebelum memasuki perkawinan. Hasil penelitian Jones (2012) menemukan bahwa, penyebab rendahnya angka kelahiran di Singapura disebabkan oleh banyak perempuan yang terlambat untuk menikah. Jones (2012) lebih lanjut mengungkapkan bahwa di Singapura banyak masyarakat yang terlambat menikah diakibatkan terlalu fokus dalam karir sehingga tidak mengutamakan untuk menikah.

Selanjutnya, jumlah anak masih hidup dalam penelitian ini berpengaruh positif terhadap jumlah anak yang diinginkan keluarga. Artinya, semakin banyak jumlah anak masih hidup pada keluarga maka semakin banyak juga jumlah anak yang diinginkan. Menurut BKKBN et al. (2013), umumnya terdapat hubungan antara jumlah anak yang diinginkan dengan jumlah anak masih hidup. Alasannya adalah keluarga akan memperbesar jumlah anak yang diinginkan seiring pertambahan jumlah anak yang mereka miliki. Menurut Singh et al. (2010) banyak keluarga akan terus memiliki anak sampai mencapai ukuran keluarga yang diinginkan.

Keluarga dengan pendapatan tinggi dalam penelitian ini cenderung menginginkan jumlah anak lebih sedikit daripada keluarga dengan pendapatan lebih rendah. Hasil penelitian ini tidak sejalan dengan hasil penelitian sebelumnya bahwa pendapatan tidak berpengaruh terhadap jumlah anak yang diinginkan (Hartoyo, Latifah, \& Mulyani, 2011). Peningkatan besar dalam pengeluaran akan mengurangi permintaan anak karena biaya setiap anak secara langsung terkait dengan pengeluaran (Becker \& Tomes, 1976). Keluarga dengan pendapatan tinggi biasanya lebih mengutamakan kualitas daripada jumlah anak. Menurut Easterlin (1975), orang tua yang lebih memberikan penekanan pada kualitas anak maka akan mengorbankan jumlah anak yang diinginkan. Dengan penghasilan tinggi, orang tua akan memberikan pendidikan dan keterampilan (kursus musik, les bahasa inggris, dan sebagainya) anak dengan sebaik-baiknya daripada orang tua dengan pendapatan rendah. Menurut Bryant (1990) pasangan kaya akan mempunyai anak lebih sedikit daripada pasangan miskin tetapi menghabiskan uang lebih banyak daripada pasangan miskin.

Penelitian ini juga menemukan bahwa sebagian keluarga (12,5\%) menyatakan bahwa tidak mempermasalahkan jenis kelamin anak. Hasil penelitian ini sejalan dengan penelitian Herarti (2004) yang melakukan penelitian di Sumedang dan Subang yang mana sebagian keluarga tidak mempermasalahkan mengenai jenis kelamin anak. Akan tetapi ketika ditanya dengan pertanyaan lanjutan, seandainya lbu memiliki 2 anak dengan jenis kelamin yang sama apakah ingin menambah lagi?, responden ada menjawab tidak, ada yang menjawab ingin mencoba menambah satu anak lagi dan bahkan ada yang menjawab akan menambah sampai mendapatkan jenis kelamin anak yang diinginkan. Tak berbeda dengan penelitian di Australia, hasil penelitian Kippen, Evans, \&Gray (2006), menemukan bahwa ibu dengan dua atau tiga anak dari jenis kelamin yang sama jauh lebih mungkin untuk memiliki anak lagi daripada ibu dengan memiliki dua atau tiga anak dari jenis kelamin berbeda.

Keluarga yang pernah mendapatkan kunjungan dan penyuluhan dari petugas $\mathrm{KB}$ (PLKB, Pos KB/Sub Pos KB/Kader KB, dan petugas kesehatan), jumlah anak yang diinginkan cenderung lebih sedikit daripada keluarga yang tidak pernah mendapatkan kunjungan petugas KB. Hasil penelitian ini mendukung pernyataan yang disampaikan oleh Suyono, Soedarmadi, \& Noerdin (2013) bahwa, peran PLKB maupun petugas KB lainnya dalam memberikan motivasi dan sosialiasi pada masyarakat mengenai norma keluarga kecil 
bahagia dan sejahtera (NKKBS) merupakan salah satu ujung tombak dari keberhasilan atau gagalnya program kependudukan dan $\mathrm{KB}$ (KKB) pada masyarakat.

\section{SIMPULAN DAN SARAN}

Hasil penelitian menunjukkan bahwa keluarga di perdesaan mempunyai karakteristik perempuan menikah di usia muda, pendapatan rendah, jumlah anak masih hidup banyak, dan sedikit yang mendapat kunjungan petugas $\mathrm{KB}$ mengakibatkan jumlah anak yang diinginkan lebih banyak daripada keluarga di perkotaan. Hasil penelitian menunjukkan bahwa variabel nilai anak dalam penelitian ini tidak memberikan pengaruh yang signifikan terhadap jumlah anak yang diinginkan. Berdasarkan hasil penelitian tersebut maka disarankan agar pemerintah lebih menggalakkan program Keluarga Berencana khususnya di keluarga perdesaan. Selain itu, untuk penelitian selanjutnya perlu dikembangkan dengan variabel bebas lainnya yang dapat menjelaskan mekanisme pengaruh nilai anak terhadap jumlah anak yang diinginkan, seperti nilai budaya dan nilai keluarga.

\section{DAFTAR PUSTAKA}

Arnold, F., Bulatao, R. A., Buripakdi, C., Chung, B. J., Fawcett, J. T., Iritani, T., Lee, S. J., \& Wu, T. S. (1975). The value of children: A cross-national study. Honolulu, US: East-West Center.

Becker, G. S., \& Tomes, N. (1976). Child endowments and the quantity and quality of children. The Journal of Political Economy, 84(4), S143-S162.

[BKKBN; BPS; KEMENKES; USAID] Badan Kependudukan dan Keluarga Berencana Nasional, Badan Pusat Statistik, Kementerian Kesehatan, United State Agency International Development. (2013). Survei Demografi dan Kesehatan Indonesia 2012. Jakarta, ID: BKKBN, BPS, KEMENKES dan USAID.

Bryant, W. K. (1990). The economic organization of the household. Cambridge, GB: Cambridge University Pr.

Buchori, N. S. (2011). Peran anak dalam pengembangan ekonomi. Jurnal Maslahah, 2(1), 37-52.

Bulatao, R. A., \& Lee, R. D. (1983). The demand for children: A critical essay. Bulatao, R. A. \& Lee, R. D., (Eds.), Determinant of fertility in developing countries volume 1: Supply and demand for children. London, GB: Academic Pr.

Buripakdi, C. (1977). The value of childre : A cross national study (volume four)Thailand. Hawaii, US: The University of Hawaii.

Davis, K., \& Blake, J. (1956). Social structure and fertility: An analytic framework. Economic Development and Cultural Change, 4(3), 211-235.

Easterlin, R. A. (1975). An Economic framework for fertility analysis. Studies in Family Planning, 6(3), 54-63.

Friedman, D., Michael, H., \& Kanazawa, S. (1994). A theory of the value of children. Demography, 31(3), 375-401.

Hartoyo, Latifah, M., \& Mulyani, S. R. (2011). Studi nilai anak, jumlah anak yang diinginkan dan keikutsertaan orang tua dalam program KB. Jur. IIm. Kel. \& Kons., 4(1), 37-45.

Herarti, R. (2004). Family planning decisionmaking: case studies in west java, indonesia. $12^{\text {th }}$ Biennial Conference population and society: Issues, Research, Policy; 15-17 September 2004, Canbera, Australia. Canberra, AU: Australian Population Association.

Jones, G. (2012). Late mariage and low fertility in singapore: the limits of policy. The Japanese Journal of Population, 10(1), 89101.

Kippen, R., Evans, A., \& Gray, E. (2006). Parental desire for sons and daughter in a western industrial setting: evidence and implications. Working Papers in Demography No 98. Canbera, AU: The Australian Nasional University.

Lucas, D., \& Meyer, P. (1990). Ekonomi kependudukan dan nilai anak. Lucas, D., McDonald, P., Young,E.,\& Young, C., (Eds.). Pengantar Kependudukan. Sumanto, N.B., \& Saladi, R., penerjemah. Yogyakarta, ID: Gadjah Mada University Pr.

Rahayu, M. L. E. E. (2009). Analisis faktorfaktor yang memengaruhi jumlah anak yang diinginkan oleh Perempuan Usia Subur (PUS) yang bekerja dan pengaruhnya terhadap pendapatan rumah tangga: studi kasus si Kecamatan Taman Kota Madiun. Jurnal Sosial, 10(1), 72-78.

Rosenzweig, M. R. (1977). The demand for children in farm households. Journal of Political Economy, 85(1), 123-146. 
Schultz, T. P. (1997). Demand for children in low income countries. In Rosenzweig MR and Stark O, editor. Handbook of population and family economics. New Haven, US: Elsever Science BV.

Singh, H. K, Singh, R. D., Singh, G. P., \& Kumar, A. (2010). Influence of sex composition on demand of child in uttar pradesh. Indian Journal of Preventive \& Social Medicine, 41(1 \& 2), 57-66.

Suyono, H., Soedarmadi, M., \& Noerdin, M. (2013). Menyegarkan pembangunan kependudukan di Indonesia: Akseptor KB membangun keluarga sejahtera. Jakarta, ID: Damandiri.

Trommsdorff, G., \& Mayer, B. (2010). Adolescents' value of children and their intentions to have children: a cross-cultural and multilevel analysis. Journal of Cross Curtural Pyschology, 41(5 \& 6), 671-689. doi:10.1177/0022022110372195.

Ushie, M. A., Enang, E. E., \& Ushie, C. A. (2013). Implications of sex preference for population growth and maternal health in obudu and obanliku, cross river state, Nigeria. Academic Research International, 4(3), 492-501. 